\title{
Litigating Economic, Social and Cultural Rights against Transnational Corporations in Indonesian Court
}

\author{
Iman Prihandono \\ Faculty of Law, Airlangga University, Indonesia. E-mail: iprihandono@fh.unair.ac.id
}

\section{ARTICLE INFO}

Keywords:

Access to Justice; Human

Rights; Transnational

Corporation

How to cite:

Prihandono, I. (2017).

Litigating Economic, Social and Cultural Rights against Transnational Corporations in Indonesian Court. Hasanuddin Law Review, 3(3): 246-262

DOI:

10.20956/halrev.v3i3.1152

\begin{abstract}
States should take appropriate steps to ensure the effectiveness of domestic judicial mechanisms when addressing business-related human rights abuses. These steps may include ways to reduce legal, practical and other relevant barriers that could lead to a denial of access to remedy. To a certain degree, these problems exist in Indonesia's judicial remedy mechanism. This article examines court decisions in five cases involving Transnational Corporations (TNCs). These decisions are examined to identify challenges and opportunities in bringing a case on ESC rights violations against TNCs. It is found that claim on ESC rights violation may be brought to the court, and the court has jurisdiction to entertain the case. However, of the five cases filed against TNCs, only in one case has the court decided in favour of the plaintiff. Most of the cases were rejected on procedural matters. This situation suggests that it remains burdensome for the victims of ESC rights violations to seek remedy at the court. There are procedural burdens that has to be faced by plaintiff when bringing ESC rights case against corporations, particularly TNCs. Nevertheless, there are new developments in relation with pursuing ESC rights in court. One of the important development is private business contract between the government and private corporations may be annulled by the court, if the exercise of the contract would violate the government's obligation to fulfil human rights of the citizens.
\end{abstract}

Copyright (C) 2017 HALREV. All rights reserved.

\section{Introduction}

Indonesia is a ratifying country to the International Covenant on Economic Social and Cultural Rights (ICESCR), ${ }^{1}$ and therefore it applies as positive law. At the same time, Indonesia is one of the world's most favoured destinations for foreign investment. ${ }^{2}$ Empirical studies show that Foreign Direct Investment (FDI) by Transnational

1 Law No. 11 of 2005 on Ratification of International Covenant on Economic, Social and Cultural Rights.

2 United Nations Conference on Trade and Development. (2009). World Investment Prospects Survey 20092011, p. 53-56. 
Corporations (TNCs) provides benefits for Indonesia national economic growth. ${ }^{3}$ However, FDI can also bring negative impacts. The negative impact of TNCs' business activities may be in the form of an environmental damage, or may potentially trigger social conflict and violence in society.

To date the Indonesian courts have examined several cases relating to the rights of economic, social and cultural (ESC rights) which are guaranteed under the ICESCR. ${ }^{4}$ However, the number of ESC rights violation lawsuit against TNCs remains relatively small. These cases are: the Lapindo mudflow case, ${ }^{5}$ the Newmont divestment of shares case $^{6}{ }^{6}$ the Indosat divestment and privatization case, the Freeport contract of work case, and the Palyja-Aetra water supply case. Unfortunately, of the five cases, only one case was successfully granted in favor of the plaintiff. The plaintiffs' arguments in Lapindo case cannot be accepted by the panel of judge. In Freeport case, the court refused to examine the case because the plaintiff lacks of legal standing. The Indosat and Newmont case was rejected based on procedural matters.

Departing from the above facts, the community's efforts in seeking justice for the remedy of ESC rights through the courts seems to be remain difficult. In contrast to some other ESC rights lawsuit that successfully granted by the court, ESC rights lawsuit against TNCs is more complex because it involves different arrays of aspects and interests. With its economic power, TNCs can influence the policy of the Indonesian government, and the effect may has an impact on the final outcome of a litigation case. Hillman and Hitt formulated three kinds of political strategies generally taken by TNCs: (1) information strategy; (2) financial incentive strategy; and (3) constituency-building strategy. These strategies are correlated with interests that are exchanged in the political contest, namely: information, money, and voters. ${ }^{7}$

In fact, foreign companies have a strong incentive to implement at least one of the strategies above. The main reason is to secure their investments and business interests. ${ }^{8}$ Moreover, TNCs realized that their bargaining power against the host government may become weaker over time. Therefore, influencing the host government's policy becomes very significant for TNCs, this is to ensure that the host government will consider their interests when formulating a policy. ${ }^{9}$ However, the interest of TNCs may be in conflict with the government's obligation to protect and fulfil ESC rights. Therefore, courts decision in lawsuits against TNCs requires further analysis and assessment; this is take lessons from previous outcomes of lawsuits against TNCs in Indonesia.

3 Blomström, M., and Sjöholm, F. (1999). “Technology Transfer and Spillovers: Does Local Participation With Multinationals Matter?". European Economic Review, 43: 915, p. 922. See also: Takii, S., and Ramstetter, E.D. (2005). "Multinational Presence and Labor Productivity Differentials in Indonesian Manufacturing 1975-2001". Working Paper Series Vol. 2004-15. The International Centre for the Study of East Asian Development, p. 22.

4 For instance, the deportation of Indonesian migrant worker case, the student national examination case, the toll road fee case, the "Operasi Yustisi" case, and the social security case.

5 Case Registration Number 384/Pdt.G/2006/PN.Jkt.Pst.

6 Case Registration Number 241/Pdt.G/2011/PN.Jkt.Pst.

7 Hillman, A.J., and Michael A. Hitt. (1999). "Corporate Political Strategy Formulation: A Model of Approach, Participation, and Strategy Decisions". Academy of Management Review, 24(4): 825.

8 Rodriguez, P., et al. (2006). "Three Lenses on the Multinational Enterprise: Politics, Corruption and Corporate Social Responsibility". Journal of International Business Studies, 37(6): 733.

9 Wan, W.P., and Hillman, A.J. (2006). "One of These Things is not Like the Others: What Contributes to Dissimilarity among MNE Subsidiaries' Political Strategy?". Management International Review, 46: 85. 
This article examines court decisions in five cases involving TNCs. These decisions are examined to identify challenges and opportunities in bringing a case on ESC rights violations against TNCs. It is found that claim on ESC rights violation may be brought to the court, and the court has jurisdiction to entertain the case. However, five cases filed against TNCs, only in one case has the court decided in favour of the plaintiff. Most of the cases were rejected on procedural matters. This situation suggests that it remains difficult for the victims of ESC rights violations to seek remedy at the court. There are prosedural burdens that has to be faced by plaintiff when bringing ESC rights case againts corporations, particulalrly TNCs. Nevertheless, there are new developments in relation with pursuing ESC rights in court. These developments are particulalrly important for the recognition of corporate responsibility to respect ESC rights, and provide hopes for the victims to obtain remedy through court litigation.

\section{Justiciability of Economic, Social and Cultural Rights and Responsibilities of Corporations}

\subsection{Justiciability of ESC Rights}

Problems in the above sections gave birth to the next issue, whether the ESC rights violations can be brought to the court. However, before further analysing this issues, it is important to discuss the term of ESC rights violations. There are a variety of terms that can be used to describe the ideal situation vis-a-vis the state's obligation to a certain standard, but is per se cannot be categorized as a violation. By giving the name of an unpleasant situation as a violation-even when the state has been trying to solve the problem of good faith and formulate ESC policy-would only distort the meaning of the word offense itself. The word 'violations' can only be used when there is a legal basis to call it, and there are legal obligations that govern the violation. ${ }^{10}$

Chapman, ${ }^{11}$ asserts three categories of ESC rights violations. First, violations arising out of government action, laws and policies. Secondly, violations stemming from discriminatory actions and policies. Third, violations arising from the failure to provide the minimum conditions (minimum core) that should exist. Meanwhile, according to the Committee on Economic, Social, and Cultural Rights, a violations does not have to be a non-compliance, certain circumstances that were not aligned or inharmonious with the ICESCR may sufficiently be regarded as a violation. Therefore, according to the Committee, with regard to the victims of violations of ESC rights, the Committee states that both individuals and groups of individuals can be categorised as victims of ESC rights violations. ${ }^{12}$

Furthermore, if violation of ESC rights is possible to take place, can the victim of this violation bring their case to the court? Looking back to Article 2(1) of the ICESCR, one may declare that dispute on the violation of ESC rights cannot be brought to court. 13 The reason for this argument is that the court should not adjudicate economic, social and cultural policies which are the rights of government as the executive body.

10 Leckie, S. (1998). "Violations of Economic, Social and Cultural Rights" in Van Boven, T.C. (ed). The maastricht Guidelines on Violations of Economic, Social and Cultural Rights. Netherlands Institute of Human Rights, vol SIM Special No. 24: 114.

11 Chapman, A.R. (1996). "A Violation Approach for Monitoring the Covenant on Economic, Social and Cultural Rights". Human Rights Quarterly, 18(1): p. 23.

12 Leckie, S. Loc. Cit.

13 Kyritsis, D. (2006). "Representation and Waldron's Objection to Judicial Review". Oxford Journal of Legal Studies, 26: 733 . 
However, the above argument may not always correct, this is because the court often makes decisions with regard to the disputed measures taken by the executive body. ${ }^{14}$ Furthermore, the examination of the case by the court does not aimed at giving an expert opinion about ESC rights. The court is performing its traditional function, that is to provide a place where the parties can be heard, assess the facts, and examining the compliance of government's action and policy with the law and regulation. ${ }^{15}$

The importance of the courts in the enforcement of ESC rights is emphasized by the Committee on Economic, Social and Cultural Rights. The Committee stated that the rigid classification of the ESC rights may put these rights beyond the reach of the courts. In the end, this situation will reduce the ability of the courts in protecting the rights of vulnerable and marginalised groups in the community. ${ }^{16}$ In translating the sentence 'progressive realisation' as stipulated in Article 2(1) of the ICESCR, the Limburg Principles state that the 'progressive realization' must be read as the government obligation to take all steps to ensure that ESC rights violations can be brought to the court.17

Apart from the Limburg Principles above, there are two other non-binding instruments which are often used to clarify the implementation of ESC rights. Both instruments emphasize the availability of remedy through the courts mechanism. The first instrument is the Bangalore Declaration. This declaration states that the absence of judicial mechanisms will increase violations in the future, this is because if violation has not been punished, there is no deterrent effect, and at the end will weaken the government's accountability. ${ }^{18}$ As for the role of judges, the Bangalore Declaration states that: 19

Judges should apply domestically international human rights norms in the field of economic, social and cultural rights. Where there is an ambiguity in a local constitution or statute or an apparent gap in the law, or inconsistency with international standards, judges should resolve the ambiguity or inconsistency or fill the gap by reference to the jurisprudence of international human rights bodies.

The second instrument is the Maastricht Guidelines. ${ }^{20}$ This Guidelines confirms that ESC rights violations can be brought to justice. The court's jurisdiction includes violations of ESC rights such as: discriminatory treatment and the application laws and regulations that results in discriminatory treatment. ${ }^{21}$ In practice, courts in many countries already receive, examine and handed down judgement on the ESC rights

14 Human Rights Features. "A Fair Deal: Justiciability of ESC Rights". Available from http://www.hrdc.net/sahrdc/hrfchr58/Issue3.htm\#A\%20fair\%20deal

15 Nolan, Porter and Langford, Op. Cit. p. 4.

16 Committee on Economic, Social and Cultural Rights, General Comment No. 9, 'The Domestic Application of the Covenant' (Nineteenth session, 1998), U.N. Doc. E/C.12/1998/24 (1998), paragraph 10.

17 The Limburg Principles on the Implementation of the International Covenant on Economic, Social and Cultural Rights. UN Doc. E/CN.4/1987/17, General Comments No. 3.

18 The Bangalore Declaration and Plan of Action (International Commission of Jurists, 1995), Paragraph 14.

19 The Bangalore Declaration and Plan of Action (International Commission of Jurists, 1995), Paragraph 18(5)(4).

20 The Maastricht Guidelines on Violations of Economic, Social and Cultural Rights (International Commission of Jurists, 1997).

21 The Maastricht Guidelines on Violations of Economic, Social and Cultural Rights (International Commission of Jurists, 1997), Guidelines No. 11-12 and No. 14(a). 
dispute. This situation is supported by the fact that many countries have incorporated elements of ESC rights into its constitution, this includes Indonesia. ${ }^{22}$

In India, in the case of Olga Tellis v. Bombay Municipal Corporation, the India Supreme Court decided that disputes relating to Article 21 of the Indian Constitution concerning the right to life can be examined by the court. This case was concerning the eviction of citizens for the reasons of development. The Supreme Court of India ruled that the eviction can only be carried out if the government provides alternative housing for evicted people. ${ }^{23}$

In the United States, a case concerning the right to live, such as: the right to sleep and to eat were examined in the Pottinger v. City of Miami case. In this case, 6,000 homeless people filed their case against the government following the police arrest, seizures of their private property, and the closing of their food sources. Judge Atkins ruled that the police action was unconstitutional because it violates the right to privacy and traveling. Eventually a compromise between the parties was reached, it was agreed that the police can not arrest the homeless people unless alternative accommodation was available. ${ }^{24}$

South Africa may be the most progressive country with respect to the role of courts in settling ESC rights disputes. The case of Government of the Republic of South Africa and Others $v$ Grootboom and Others (Grootboom case) is an important case in which the Constitutional Court of South Africa stated that the state is obliged by the constitution to fulfil the ESC rights, and the court is mandated by the constitution to enforce this government's obligation. Therefore, the state is obliged to create a policy to guarantee access to property ownership, and adequate housing. If the substitute of adequate housing substitute is not available, then the state cannot force the people to move from their community. ${ }^{25}$

In the Minister of Health and Others $v$ Treatment Action Campaign and Others, a nongovernmental organization filed a legal suit against the government, demanded that the government should run a program to provide Nevirapine, an HIV antiviral drug for pregnant mothers who tested HIV positive. The Constitutional Court of South Africa ruled that it would be difficult to immediately provide access to anyone to get this medicine, but the government must act progressively. Nevirapine should be immediately available in public hospitals and government clinics. ${ }^{26}$

In Canada, the Supreme Court of Canada decided in the case of Eldridge v. British Columbia (Attorney General), that the government's failure to provide an interpreter for person with hearing disability in the canter of health service discriminates against the

22 Countries which include ESC Rights in their constitution: Argentina, Belarus, Belgium, Bolivia, Brazil, Bulgaria, Cape Verde, Chile, Colombia, the Democratic Republic of Congo, Costa Rica, Croatia, the Czech Republic, Denmark, Ecuador, El Salvador, Estonia, Ethiopia, Finland, France, Germany, Greece, Guatemala, Honduras, Hungary, India, Indonesia, Ireland, Italy, Japan, the Republic of Korea, Latvia, Lithuania, Macedonia, Mexico, Mongolia, Morocco, Mozambique, the Netherlands, Nicaragua, Norway, Paraguay, Peru, Poland, Portugal, Romania, Russia, Senegal, Slovakia, Slovenia, South Africa, Spain, Syria, Switzerland, Thailand, Uruguay and Venezuela.

23 Olga Tellis v. Bombay Municipal Corporation, 19853 SSC 545.

24 Pottinger v. City of Miami, 810 F. Supp.1551 (1992), 16 November 1992.

25 Government of the Republic of South Africa and Others $v$ Grootboom and Others [2000] ZACC 19, 2001 (1) SA 46 (CC), 2000 (11) BCLR 1169 (CC).

26 Minister of Health and Others $v$ Treatment Action Campaign and Others (No 1) (CCT9/02) [2002] ZACC 16; 2002 (5) SA 703; 2002 (10) BCLR 1075 (5 July 2002). 
right to obtain the same advantages of legislation - the rights to equal benefit of the law. ${ }^{27}$

In addition to the national courts, disputes on ESC rights may also be brought to a regional court by using regional human rights instruments. The Inter-American Court of Human Rights has handed down its decision on ESC rights dispute in the case of Awas Tingni $v$. Nicaragua. In this case the court ruled that the state must immediately stop giving permits for logging activity on communal lands and indigenous heritage. Furthermore, the state should provide a clear boundary (demarcation) line, and land rights for the communal land. ${ }^{28}$ Likewise, the European Court of Human Rights in the case Gaygusuz v. Austria decided that different treatment based on citizenship, and not based on an objective assessment and reasonable justification of the right to social security is a discriminative action. ${ }^{29}$

\subsection{Responsibility of TNCs Towards ESC Rights}

Based on the above discussion, it is clear that disputes on ESC rights may be submitted to the court. Courts in many countries have also expressly states that they have jurisdiction to receive, examine and rule on the dispute of ESC rights violations. The next major issue is whether a legal entity such as a corporation has a responsibility towards the fulfilment of ESC rights? Furthermore, if the dispute involving the fulfilment of ESC rights can a corporation also be brought to justice? These problems will be discussed further in this sub-section.

In addressing the issues of corporate responsibility towards ESC rights, the current international human rights law instruments expressly imposes direct responsibility to the state, but not to non-state actors, including corporations. ${ }^{30}$ The responsibility to fulfil ESC rights is mandated to the state, and states are obliged to prevent a third party-including corporations-from violating ESC rights. ${ }^{31}$ However, another opinion stating that individuals or groups and group of persons has a duty what is called as a duty not to do harm under the ESC rights convention. The ICESCR Article 5 provides:

"Nothing in the present Covenant may be interpreted as implying for any State, group or person any right to engage in any activity or to perform any act aimed at the destruction of any of the rights or freedoms recognized herein...".

The responsibility of corporation/private business sector in the fulfilment of ESC rights affirmed by the Committee on Economic, Social and Cultural Rights, in particular on the right to food, in one of its document, the Committee's states:32

"... while only States are parties to the Covenant and are thus ultimately accountable for compliance with it, all members of society-individuals ... as well as the private business sector-have responsibilities in the realization of the right to adequate food ... the private

27 Eldridge v. British Columbia (Attorney General), 151 D.L.R. (4th) 577, 616 (1997).

28 Mayagna (Sumo) Community Awas Tingni v. Nicaragua, Inter-American Court of Human Rights, August 31, 2001, p. 148-154.

29 Gaygusuz v. Austria, European Court of Human Rights, September, 16, 1996, para. 46-52.

30 David Weissbrodt and Muria Kruger. (2005). "Human Rights Responsibilities of Business as Non-State Actors" in Alston, P. (ed). Non-State Actors and Human Rights. p. 315, p. 332.

31 Sanchez-Moreno, M. M., \& Higgins, T. (2003). “No Recourse: Transnational Corporations and the Protection of Economic, Social and Cultural Rights in Bolivia." Fordham International Law Journal, 27, 1663.

32 U.N. Econ. \& Soc. Council, Committee on Economic, Social \& Cultural Rights, General Comment 12: The Right to Adequate Food (Art.11), 20th Sess., U.N. Doc. E/C.12/1999/5 (1999). 
business sector-national and transnational-should pursue its activities within the framework of a code of conduct conducive to respect of the right to adequate food, agreed upon jointly with the Government and civil society."

Furthermore, other documents concerning the right to health, the Committee on Economic, Social and Cultural Rights states that a state must carry out its international obligations on ESC rights by requiring everyone within its jurisdiction to take certain actions. ${ }^{33}$ In addition, the state has an obligation to the international human rights legal instruments to conduct horizontal implementation to the instrument within its territory. ${ }^{34}$

Horizontal obligation of the state means that the state is responsible for the actions of every person within its territory, and state can be held accountable for violations of international human rights, including by private legal entity that occurred in its territory. This means that any private legal entities have a duty not to violate human rights, because every offense will be punished by the state. ${ }^{35}$ Likewise, the state has an obligation to protect ESC rights without discrimination. Violations by all parties, both individuals and corporations will result to legal consequence. ${ }^{36}$

The discussion above shows that corporations and other private legal entities have the obligation not to violate ESC rights. However, the next issue is whether ESC rights violations by the corporation can be brought to justice. Another problem is whether the victim can directly sue the corporation on the basis of ESC rights violations, when the obligation to prosecute rests with the government. Should the government file a lawsuit against the corporation for the interest of the victims? An explanation of these issues will be carried out through a comparison of several ESC rights cases in several jurisdictions below.

The first case is the Social and Economic Rights Action/Center for Economic and Social Rights (SERAC and CESR) v. Nigeria which was examined by the African Commission on Human and Peoples' Rights. ${ }^{37}$ This case relates to environmental degradation in Ogoni-Nigeria, which arising from oil exploration cooperation project between the government and Shell Petroleum Development Corporation, a transnational corporations based in the Netherlands. The panel judge ruled that the government violated its obligation to fulfil the right to health and healthy environment for the action of attacking, burning and destroying several Ogoni villages. ${ }^{38}$ With regard to the government's obligation to protect, it was decided that the government should protect the interests of the ESC rights holders from any political, economic and social intervention. ${ }^{39}$

33 U.N. Econ. \& Soc. Council, Committee on Economic, Social \& Cultural Rights, General Comment 14: The Right to the Highest Attainable Standard of Health (Art. 12), 42, 22d Sess., U.N. Doc. E/C.12/2000/4 (2000).

34 Joseph, S. (2004). Corporations and Transnational Human Rights Litigation. Hart Publishing, p. 9.

35 Kinley, D., and Joseph, S. (2002). "Multinational Corporations and Human Rights: Questions about their Relationship: A New Research Project Studying the Evolving Legal and Human Rights Responsibilities of Corporations". Alta Law Journal , 27: p. 7-8.

36 U.N. Econ. \& Soc. Council, Committee on Economic, Social \& Cultural Rights, General Comment 3: The Nature of States Parties' Obligations (Art. 2, para. 1), 5th Sess., U.N. Doc. E/1991/23 (1990).

37 SERAC and CESR v. Nigeria, African Commission on Human and Peoples' Rights, Communication $\mathrm{N}^{\circ}$ 155/96, October 13-27, 2001.

$38 \quad$ Ibid p. 54.

39 Ibid p. 46. 
In Europe, the European Court of Human Rights examined the case of Costello-Roberts $v$. The United Kingdom concerning violence by teachers against student in a private school in the UK. The court ruled that the state cannot be released from its obligation by delegating the responsibility to protect the ESC rights to a private entity. ${ }^{40}$

In Colombia, the Constitutional Court ruled that termination of the student's enrolment for the reason of pregnancy is violating the right to education. The court ordered the private school in which the student was enrolled to accept the student back and to continue her study. ${ }^{41}$ Furthermore, the Supreme Court of Argentina in the case Etcheverry v. Omint decided that the denial of a health insurance company to continue the insurance coverage to an HIV-positive is a violation of the right to health. The court ruled that the insurance company should continue to the insurance agreement and provide insurance protection. ${ }^{42}$

Based on the four cases above, it appears that the courts in some jurisdictions have taken different approaches with regard to corporate responsibility towards ESC rights. Regional court of human rights in African and European region still adheres to the approach that states is the primary responsibility holder of ESC rights. Therefore, the court decision was to order the states to take steps to rehabilitate the damage, regardless the fact that the pollution in the Ogoni was caused by corporations, and violence in the private schools in the UK were committed by the employees of the corporation. However, another approach can be found in Colombia and Argentina. The court had decided that ESC rights violations have been committed by a private legal entity, and therefore the private entity must directly take necessary actions to the victims.

\section{Legal Actions on ESC Rights and Transnational Corporations (TNCs) in Indonesia}

\subsection{Indosat case (2005)}

The privatization case of PT Indosat through divestment of its shares was probably the first case concerning ESC rights which involve conflict between the interests of the public and the business interests of TNCs. In this case a number of individuals filed an actio popularis or the citizen law suit against three parties, namely the Government of Indonesia c.q. Ministry of State-Owned Enterprises; STT Communications Limited (STT); and Indonesia Communications Limited (ICL). The reason for this lawsuit was the sale of PT Indosat shares as stipulated in the Shareholder Agreement (SA) and the Share Purchase Agreement (SPA) dated December 15, 2002 between the Indonesia's Ministry of State Owned Enterprises, and two corporations: the STT and the ICL.

Through these agreements, the government sold the 41.49 percent of its shares in PT Indosat. Following this sale, the government's share in PT Indosat remaining only 15 percent. Whereas, in an earlier transaction, 35 percent of PT Indosat shares which was owned by PT Telkom (another Indonesian state-owned telecomunication company) have also been transferred to Temasek Holdings through its two subsidiaries namely: STT and SingTel. In another words, the Indonesian telecommunications industry has

40 Costello-Roberts v. The United Kingdom, 247 European Court of Human Rights (ser. A) 50, p. 28.

41 Colombian Constitutional Court, Case T-211/95, May 12, 1995.

42 Etcheverry, Roberto E. v. Omint Sociedad Anónima y Servicios, Argentine Supreme Court, Attorney General's brief of December 17, 1999, and Judgment of the Court of March 13, 2001. 
technically and substantively been under the control of Temasek Holdings, Singapore. 43

The plaintiffs argued that privatization of PT Indosat through divestments scheme as stipulated in the SA and the SPA agreements was in violation of the Indonesian Limited Liability Company Law, the Foreign Direct Investment Law and the Capital Market Law. Thus, the divestment may be qualified as unlawful agreement (ongeoorloofde oorzaak). ${ }^{4}$

Though plaintiffs did not refer directly to the ESC rights, the plaintiffs clearly refer to the economic, culture and education interests that should be protected by the government in this case. The plaintiffs argued that the transfer of a majority of shares in PT Indosat to foreign corporations may be resulted in the transfer of frequency SLOT which owned by PT Indosat to foreign companies. Whereas, this frequency SLOT is crucial for Indonesia in improving its economic, cultural, security, strategic, defense, and education. ${ }^{4} 5$

Unfortunately, this claim was unsuccessful both in the court of first instance and the appeal court. In its decision, the District Court of Central Jakarta ruled that the use of actio popularis or citizen law suit mechanism is unacceptable under the Indonesia Law on Civil Procedure. ${ }^{46}$ The decision was confirmed by the Jakarta High Court. ${ }^{47}$ The plaintiffs filed a final appeal, and the Supreme Court upheld the decision of the first instance court and the appeal court.

The panel judges at the Supreme Court decided that the term 'judge made law' can be viewed from two sides, namely the rechtsvinding and the rechtsschepping, but rechtsvinding and rechtsschepping can only be performed by the judges if the procedural law exists. There are two important issues that must be considered in achieving fairness in law enforcement and justice, these are: (1) the procedures for law enforcement (procedural justice); and (2) the relation between rules in the law enforcement process (substantiva justice). Particularly in law enforcement, the way that the law should be enforced is very important, this is because justice cannot be achieved through an unfair procedure. Therefore, because the basis of the claim was based on method that has not been regulated in the Indonesian Law on Civil Procedure, therefore, the lower court we correct in applying the law. ${ }^{48}$ As such, the actio pupolaris suit by the plaintiffs cannot be recognised and inacceptable.

\subsection{Lapindo case (2006 and 2007)}

The mudflow case in Sidoarjo took place at a drilling site operated by PT Lapindo Brantas (a company which at the time the mudflow was first occured partly owned by Santos Brantas Pty Ltd-a subsidiary of Santos Ltd., an Australia based mining company) was one of the best examples of the negative impact of TNCs' business operations in Indonesia. The Indonesian Forum for Environment (WALHI) filed an unlawful conduct lawsuit based on Law Number 23 of 1997 on Environmental Management for the environmental damage in Porong, as a result of the mudflow

43 Decision of the Supreme Court No. 2280 K/Pdt/2005, 19 June 2006, p. 53.

44 Ibid, p. 34.

45 Ibid, p. 30.

46 Decision of the District Court of Central Jakarta No. 178/PDT.G/2003/PN.JKT.PST, 6 November 2003.

47 Decision of the High Court of Jakarta No. 126/PDT/2004/PT.DKI, 24 September 2004.

48 Decision of the Supreme Court No. 2280 K/Pdt/2005, 19 June 2006, p. 59. 
incident. ${ }^{49}$ In addition, WALHI also bases its claim on Government Regulation No. 27 Year 1999 on Environmental Impact Assessment (EIA), as well as the Ministery of Environment Decree No. 17 of 2001 on Mandatory Types of Businesses which should conduct EIA. 50

In this case, the judges came to a conclusion that "... the mud flow is a result of a natural phenomenon and was not the result of the the defendant's failure to follow standard drilling procedures". Relating to the responsibilities of the corporate defendant based on the Law on Environmental Management, the judges decided that "the fact that the mudflows took place in the drilling site of Lapindo Brantas Inc., therefore, the company has a social responsibility in assisting the government to cope with the impact of the mudflow". Unfortunately, this lawsuit was rejected, and WALHI was sentenced to pay the court fees. 51

Previously, another NGOs standing lawsuit was filed by the Indonesian Legal Aid Foundation (YLBHI). The President of the Republic of Indonesia, the Minister of Energy and Mineral Resources, Ministry of Environment, BP Migas, the Governor of East Java, the Sidoarjo Regent, and Lapindo Brantas Inc. were all being brought to the District Court of Central Jakarta. The plaintiff alleged that the government and Lapindo Brantas Inc. were not serious in restoring the rights of victims and to stop the mudflow. 52 The Government considered to have committed an unlawful conduct and in violation of the Law No. 11 of 2005 on the Ratification ICESCR.53

In its decision the judges argued that the government and Lapindo Brantas Inc. has made optimum efforts in restoring the victims' rights, and to stop the mudflow. A sum of money amounting at 6.1 billion rupiah which had spent by Lapindo Brantas Inc. has shown its good faith in handling the mudflow incident.54 Thus, the panel of judges came to a conclusion that one of the elements of unlawful misconduct has not been satisfied, and rejected the entire claim of the plaintiff. Against this decision, YLBHI filed an appeal arguing that the decision of the judges has a number of substantial errors. ${ }^{55}$

\subsection{Newmont case (2011)}

In the divestment of PT Newmont Nusa Tenggara (PTNNT) case, the plaintiff used citizen law suit mechanism. This lawsuit was filed by the residents of West Nusa Tenggara which organised under the Civil Society for Public Welfare. In this case the plaintiff sued the Ministry of Finance, the Government Investment Center, PTNNT, and Newmont Mining Corporation. The reason for this lawsuit was the purchase of $7 \%$ of the divested shares of PTNNT by the Ministry of Finance and the Government Investment Center on May 6, 2011. The plaintiff argued that the purchase will not bring

49 Decision of the District Court of South Jakarta No.: 284/Pdt.G/2007/PN.Jak.Sel.

50 Hukumonline.com, "Lapindo dan Pemerintah Digugat Lagi", Available online at: http://www. hukumonline.com/detail.asp?id=16205Ecl=Berita, Accessed on 15 October 2014.

51 Ibid.

52 Hukumonline.com, "Pemerintah dan Lapindo Sudah Bertanggungjawab, Gugatan YLBHI Ditolak", Available online at: $h t t p: / / w w w . h u k u m o n l i n e . c o m / d e t a i l . a s p ? i d=18074 \mathcal{E} \mathrm{cl}=$ Berita, Accessed on 15 October 2014.

53 Decision of the District Court of Central Jakarta No.: 384/Pdt.G/2006/PN.JKT.PST.

54 Ibid.

55 Hukumonline.com, “YLBHI Resmi Ajukan Banding”, Available online at: http://www.hukumonline. com/detail.asp? $i d=18159 \mathcal{E} \mathrm{cl}=$ Berita, Accessed on 15 October 2014. 
significant impact to the improvement of economic, livelihood and prosperity of the West Nusa Tenggara residents. ${ }^{56}$

The plaintiffs requested that the purchase of PTNNT shares by the central government should be annulled by the court. Furthermore, the plaintiff also requested the central government to transfer its rights to purchase the divested shares of PTNNT to the local governments or other entity appointed by the local government. The benefit from the shares will then be distributed to the residents of West Nusa Tenggara through community development and empowerment programs. In this lawsuit, the plaintiffs claimed that the purchase of PTNNT divested shares by the central government is violating their rights to a decent life, and the right to security and prosperity. The plaintiffs have been the victims of conflict and violence as a result of the mining activities of PTNNT. Therefore, it is their rights to get the benefit out of PTNNT mining operation. In its lawsuit, the plaintiffs directly refer to the Article 11(1) and (2) of the ICESCR. 57

In its decision, the panel of judge at the District Court of Central Jakarta declared that the lawsuit cannot be accepted for procedural reason. The plaintiff failed to satisfy the notification procedure. According to the judges, since the rule and procedure for the citizen law suit is still absent, then the procedure for this legal action should follow the procedure as practiced in the United States, and courts in other common law jurisdiction. The judges stated that seven days notification by the plaintiff did not satisfy the 60 days notification as commonly practised in common law jurisdiction. Thus, the plaintiff's claim was declared as premature, and cannot be examined by the court. 58

\subsection{Freeport case (2011)}

In this lawsuit, an organization named the Indonesian Human Rights Committee For Social Justice (IHCS) requested the cancellation of PT Freeport Indonesia's Contract of Work (CoW). The plaintiff sued PT Freeport Indonesia, the Ministry of Energy and Mineral Resources, the President of the Republic of Indonesia and the Parliament of the Republic of Indonesia. This lawsuit concerns the royalty under the CoW of PT. Freeport Indonesia. The royalties that had been paid by PT. Freeport Indonesia amounting to 1 percent of production of gold mine operation. This royalty is far below the amount of royalty that stipulated in Government Regulation No. 45 of 2003 on the State's Non Tax Income.

The Government Regulation 45/2003 stipulates that the royalty for gold mine is at 3.75 percent of the selling price/ton, copper is amounted at 4 percent of the sales price/kilo, and silver is set at 3.25 percent of the sales price/kilo. Therefore, the plaintiff filed a request for damages amounting at USD254 million, to compensate the loss of royalties for the period of 2003 until 2011. ${ }^{59}$

56 Antara News, "Warga NTB Berharap Menkeu Pahami Gugatan Divestasi", Available online at: http://mataram.antaranews.com/print/17622/warga-ntb-berharap-menkeu-pahami-gugatan-divestasi, Accessed on 30 October 2014.

57 Ibid.

58 Decision of the District Court of Central Jakarta No. 241/Pdt.G/2011 / PN.Jkt.Pst. 21 November 2011.

59 Ipotnews, News Opinion: Natural Resources, "Gugatan Royalti Kontrak Karya Freeport Tidak Diterima", Available online at: https://www.ipotnews.com/m/article.php?jdl=Gugatan_Royalti_Kontrak_ Karya_Freeport_Tidak_DiterimaElevel2 $=$ newsandopinionElevel3 $=\mathcal{E} l e v e l 4=$ natural $\% 2520$ resources $\mathcal{E} i d=15830$ 14, accessed 30 October 2014. 
Although the plaintiff did not directly address that their complaint was based on the ESC rights violations. However, this claim was aiming at protecting public interest which may have an impact to the fulfilment of ESC rights. The state has an obligation to manage natural resources and to use it for the maximum interests of the people. The failure of states to manage natural resources would negatively affect the dignity of life and the welfare of its citizen. In its decision, the panel of judges at the District Court of South Jakarta rejected this claim on the grounds that the plaintiff lacks of legal standing to bring this case. 60

This lawsuit was rejected because the plaintiff is not an environmental or consumer protection organization, whereas the NGOs' standing to file a lawsuit has only been recognised by the Law on Environmental Management, and the Law on Consumer Protection. The judges argued that this lawsuit is concerning the CoW which entered into between the Government of Indonesia and PT Freeport Indonesia. This contract falls within the realm of private and business law, and therefore is not related to the problems of the fulfilment of human rights. Since the purpose and functions of the plaintiff's organization is related to human rights, the plaintiff lacks of standing to bring this claim. 61

\subsection{Palyja-Aetra case (2015)}

In this case, a number of individuals and civil society organizations filed a lawsuit using the CLS mechanism against several government agencies and the Jakarta Municipal Government as Defendant, and PT PAM Lyonaise Jaya (Palyja) and PT Aetra Air Jakarta (Aetra), respectively as co-defendant I and co-defendant II. The main request of the plaintiff in this case was the cancellation of the water management cooperation agreement between PT PAM Jaya and its foreign partners: Palyja and Aetra, which entered into between the parties since 1997.

The plaintiffs argued that the cooperation agreement had resulted in the loss of the right to water for the residents of the city of Jakarta. The transfer of assets of PAM Jaya, the procurement of new assets, and the sale of assets that are not accounted for has burdened the municipal government's budget, thus making the price of water to be expensive. This situation constitutes an infringement of Articles 11 and 12 of the International Covenant on Economic, Social and culture that has been ratified by Law No. 11 of 2005.

In its decision the panel of judges at the District Court of Central Jakarta ruled that the Municipal Government of Jakarta has breach the water management law by delegating the authority to distrbute water to private entities. The court also stated that the defendat was negligent in assuring the fulfillment of the rights to water for its residents. The court has ordered the municipal government of Jakarta to end the water management agreement, and returning the management of water management and distribution to PAM Jaya (a government owned water company). This is in accordance with the Municipal Government Regulation No. 13 year 1992 on the City-Owned Water Operator.

60 Decision of the District Court of South Jakarta No.331/Pdt.G/2012/PN.Jkt.Sel.

61 Ibid. 


\section{ESC Rights Disputes: Opportunities and Challenges}

\subsection{Opportunities}

One of the most important opportunity is the admissibility of ESC rights lawsuit. Indeed, a number of lawsuits related to ESC rights have been granted by the judges. The courts had granted in favor of the plaintiff in three landmark cases: the Migrant Workers case, the National Examination case, and the Social Security case. These case may indicate the improvement of access to justice for the victims of ESC rights violations.

The other opportunity is that the victims of ESC rights violations have been able to employe various types of lawsuit mechanisms, these are: the Class Action; the NGO's Standing; and the Citizen Law Suit (CLS) mechanism. In particular, the CLS mechanism was utilised in the Migrant Workers case, the National Examination case, and the Social Security case. Likewise, in four cases against TNCs, CLS mechanism was used in the case of Indosat and Newmont case. While the NGOs' Standing mechanism was used in the other two cases, namely: the Lapindo case and the Freeport case.

Particularly for the CLS, this seems to be the most utilised mechanism in ESC rights disputes in Indonesia. Of the five cases analysed, it appears that there has been a significant change in the recognition of the CLS mechanism by the court. Starting from the Indosat case where CLS/action popularis lawsuit has not yet recognised by the court. In Indosat case the judge at the court of first instance, the appeal court, and the Supreme court took the same opinion, the CLS lawsuit has not been set in the Indonesia Law on Civil Procedure. Therefore, CLS lawsuit mechanism cannot be accepted by the court.

Furthermore, there are three significant developments in relation to civil suit on the violations of ESC rights against corporations in Indonesia. First, a private business contract between a government body and a private corporation can be declared void by the court. Particularly, when the exercise of the contract violates the government's obligation to fulfill human rights of its citizens. This situation may be found in the judgment Palyja/Aetra case.

Second, citizens may have legal standing even if they are not parties to the business agreement between the government and a business entity. In the CLS, the plaintiff does not have to prove the injury. The CLS has a different procedure with the ordinary civil lawsuit procedure. In the common procedure, the plaintiff should be a party to the agreement to show the damages it suffered. ${ }^{62}$

Third, the notification requirement in the CLS procedures is no longer a problem since the issuance of the Decree of the Chief Justice of the Supreme Court No. 36/KMA/SK/II/2013 on the Adjudication Guidelines for Environmental Case. Although the Decree was intended to provide guideline for judges in adjudicating environmental cases, this decree also provide guidance to judges in examining cases using CLS procedures.

Previously, notification requirement was the main obstacle in the CLS lawsuit. This barrier may be found in the Indosat case and the Newmont case. Both of these cases were unaccepted because of the unclear procedure of CLS lawsuit at that time.

62 Decision of the District Court of Central Jakarta No. 527/Pdt.G/2012/PN.Jkt.Pst tanggal 20 Februari 2015, p. 246. 
The Newmont case perhaps was the most important example for the ESC rights lawsuit againts TNCs in Indonesia. The Newmont case was unaccepted by the court because the plaintiff failed to fulfill the 60 days notification requirement. Unfortunately this notification requirement was not known in Indonesian law on civil procedure. The 60 day notification requirement was adopted from the practice by courts in the common law jurisdiction.

Fortunately, since the enactment of the Decree of the Chief Justice of the Supreme Court No. 36/KMA/SK/II/2013 on the Adjudication Guidelines for Environmental Case, the rules on notification in CLS mechanism provides a clear guideline. Notification shall be filed within 60 working days before the lawsuit filed, and it is a compulsory process. If plaintiff failed to notify the defendant, the court will refuse to adjudicate the case. The plaintiff must also send a notification to the defendant with a copy to the Chairman of the District Court. Another important feature is that the period of 60 working days aims at providing opportunity for the Government to fulfill its legal obligations as requested or required by the plaintiff.

\subsection{Challenges}

Unfortunately, apart from from the opportunities mentioned above, ESC rights lawsuit aganits corporations in civil court in Indonesia still encounter some challenges. Among the challenges that exist, there are at least two major obstacles, these are: (a) the corporation cannot be sued directly in the violation of human rights, because the state is the main duty bearer who has responsibility to respect, protect and fulfill the human rights; and (b) the organizations do not have legal standing to file legalsuit in the interests of human rights, since organization lawsuit is only recognized in environmental and consumer protection cases.

First, in some lawsuits concerning the violations of ESC which corporation is involved, it appeared that the corporation was in a position as co-defendants. Corporation's posititon as co-defendant appeared in all five cases which are analyzed in this paper. Thus, the government has not yet moved from its position as a major duty bearer to respect, protect and fulfill human rights.

Implicitly, judges in ESC rights lawsuit has declared that corporations have a responsibility to the ESC rights. For example, in the Lapindo case brought by YLBHI. The judges argued that the IDR6.1 trillion amount of money which has been given by PT Lapindo is a form of good faith in mitigating the mudflow disaster. ${ }^{63}$ Similarly, in the Lapindo case brought by WALHI, the judges decided thet PT Lapindo has a social responsibility to help the government in mitigating the impact of the mudflow. ${ }^{64}$

From the language used by the judges in both Lapindo cases above, it showed that corporate responsibility in human rights remain limited only to support the government. Meanwhile, the efforts of the company to mitigate the mudflow disaster was not considered as performing its legal responsibility but it was merely regarded as an act of good faith. Thus, a direct recognition to the responsibility of corporation on ESC rights violations caused by their operations has not yet exist.

63 Decision of the District Court of Central Jakarta No.: 384/Pdt.G/2006/PN.Jkt.Pst.

64 Hukumonline.com, "Lapindo dan Pemerintah Digugat Lagi", Available online at: http://www.hukumonline.com/detail.asp?id=16205Ecl=Berita, accessed 15 October 2014. 
Secondly, in relation to human rights defenders which have no legal standing to bring lawsuit on ESC rights. This is as shown in the Freeport case. This situation is unfortunate because the judges still limits its jurisdiction on the existing law. In fact, if the judges in the case of the CLS mechanism can take a lesson from the notification process which is practiced in the common law system court, there is no reason why Indonesian judges did not take the same lesson about the right of human rights organization to bring a case in human rights issues.

The judges in the Indonesian court can take a lesson from the South African courts which accepted the organization lawsuit (legal standing) in the case of Minister of Health and Others v. Treatment Action Campaign and Others. In many ways, the civil court in Indonesia can learn from the practices of the Indonesian Constitutional Court. The Constitutional Court has several times entertain constitutional review case brought by organizations and human rights defenders, for instance constitutional review case on the law concerning the management of natural resources

\section{Conclusion}

The ESC rights disputes is justiciable to be examined and decided by the courts. The ESC rights lawsuit in Indonesian court is possible because legal instruments to respect, protect and fulfill of ESC rights have been available. Moreover, there are cases concerning fulfillment of ESC rights that have been settled by the courts, in favor of the victim. This is as showed in the Migrant Workers case, the National Examination case, and the the Social Security case. In the same way, the ESC rights violation lawsuit against TNCs have been made possible. However, in all of the five cases that analyzed in this paper, TNCs were in the position of co-defendant. The government and/or the government organs were in the position as the main defendant. It seems that the plaintiff still adheres to the idea that state hold the primary duty to respect, protect and fulfill human rights. Therefore, the state should be placed as the main defendant. Whereas lessons from other countries shows that the court has made a decision which directly punish the corporations whose actions impede the fulfillment of ESC rights.

Consequently, there are several opportunities and challenges in ESC rights lawsuit against TNCs in Indonesian courts. The Indonesian court has the competence to examine and decide cases of ESC rights through through three different lawsuit mechanisms, these are the class action mechanism, legal standing mechanism (the Lapindo case), as well as the citizen law suit mechanism (the Indosat, Newmont, Freeport and Palyja/Aetra cases). However, the court still has not been able to receive legal standing lawsuit submitted by human rights organizations.

Above all, although the Indonesian courts are open for ESC rights violation cases, several aspects need to be improved. The most important aspect for enhancement is to improve the knowledge of the judges on ESC rights and human rights law in general. These steps need to be taken so that when examining a case, the judge should not base their arguments only on the existing legal rules. The judges need to learn from the decision of foreign jurisdictions. The characteristics of a dispute with human rights dimension is somewhat different from the general civil case disputes. The most important aspect is that the fulfillment of human rights cannot be delayed. Perhaps human rights training for judges is urgently needed. With this capacity building program, it may be expected to a better condition for "respect, protect and fulfill" of human rights in Indonesia. 


\section{References}

Blomström, M., and Sjöholm, F. (1999). “Technology Transfer and Spillovers: Does Local Participation with Multinationals Matter?" European Economic Review, 43: 915.

Chapman, A.R. (1996). "A Violation Approach for Monitoring the Covenant on Economic, Social and Cultural Rights". Human Rights Quarterly, 18(1): 23.

Committee on Economic, Social and Cultural Rights, General Comment No. 9, 'The Domestic Application of the Covenant' (Nineteenth session, 1998), U.N. Doc. E/C.12/1998/24 (1998).

David Weissbrodt and Muria Kruger. (2005). "Human Rights Responsibilities of Business as Non-State Actors" in Alston, P. (ed). Non-State Actors and Human Rights.

Hillman, A.J., and Michael A. Hitt. (1999). "Corporate Political Strategy Formulation: A Model of Approach, Participation, and Strategy Decisions". Academy of Management Review, 24(4): 825.

Joseph, S. (2004). Corporations and Transnational Human Rights Litigation. Hart Publishing.

Kinley, D., and Joseph, S. (2002). "Multinational Corporations and Human Rights: Questions about their Relationship: A New Research Project Studying the Evolving Legal and Human Rights Responsibilities of Corporations". Alta Law Journal , 27.

Kyritsis, D. (2006). "Representation and Waldron's Objection to Judicial Review". Oxford Journal of Legal Studies, 26: 733.

Leckie, S. (1998). "Violations of Economic, Social and Cultural Rights" in Van Boven, T.C. (ed). The maastricht Guidelines on Violations of Economic, Social and Cultural Rights. Netherlands Institute of Human Rights, vol SIM Special No. 24: 114.

Rodriguez, P., et al. (2006). "Three Lenses on the Multinational Enterprise: Politics, Corruption and Corporate Social Responsibility". Journal of International Business Studies, 37(6): 733.

Sanchez-Moreno, M. M., \& Higgins, T. (2003). “No Recourse: Transnational Corporations and the Protection of Economic, Social and Cultural Rights in Bolivia." Fordham International Law Journal, 27, 1663.

Takii, S., and Ramstetter, E.D. (2005). “Multinational Presence and Labor Productivity Differentials in Indonesian Manufacturing 1975-2001". Working Paper Series Vol. 2004-15. The International Centre for the Study of East Asian Development, 22.

U.N. Econ. \& Soc. Council, Committee on Economic, Social \& Cultural Rights, General Comment 12: The Right to Adequate Food (Art.11), 20th Sess., U.N. Doc. E/C.12/1999/5 (1999).

U.N. Econ. \& Soc. Council, Committee on Economic, Social \& Cultural Rights, General Comment 14: The Right to the Highest Attainable Standard of Health (Art. 12), 42, 22d Sess., U.N. Doc. E/C.12/2000/ 4 (2000).

U.N. Econ. \& Soc. Council, Committee on Economic, Social \& Cultural Rights, General Comment 3: The Nature of States Parties' Obligations (Art. 2, para. 1), 5th Sess., U.N. Doc. E/1991/23 (1990).

United Nations Conference on Trade and Development. (2009). World Investment Prospects Survey 2009-2011.

Wan, W.P., and Hillman, A.J. (2006). "One of These Things is not Like the Others: What Contributes to Dissimilarity among MNE Subsidiaries' Political Strategy?". Management International Review, 46: 85. 


\section{Court Decisions}

Colombian Constitutional Court, Case T-211/95, May 12, 1995.

Costello-Roberts v. The United Kingdom, 247 European Court of Human Rights (ser. A) 50.

Decision of the District Court of Central Jakarta No.: 178/PDT.G/2003/PN.JKT.PST, 6th November 2003.

Decision of the District Court of Central Jakarta No.: 241/Pdt.G/2011 /PN.Jkt.Pst. 21st November 2011.

Decision of the District Court of Central Jakarta No.: 384/Pdt.G/2006/PN.JKT.PST.

Decision of the District Court of South Jakarta No.: 284/Pdt.G/2007/PN.Jak.Sel.

Decision of the District Court of South Jakarta No.: 331/Pdt.G/2012/PN.Jkt.Sel.

Decision of the High Court of Jakarta No.: 126/PDT/2004/PT.DKI, 24th September 2004.

Decision of the Supreme Court No.: 2280 K/Pdt/2005, 19th June 2006.

Decission of the District Court of Central Jakarta No.: 527/Pdt.G/2012/PN.Jkt.Pst, 20th February 2015

Eldridge v. British Columbia (Attorney General), 151 D.L.R. (4th) 577, 616 (1997).

Etcheverry, Roberto E. v. Omint Sociedad Anónima y Servicios, Argentine Supreme Court, Attorney General's brief of December 17, 1999, and Judgment of the Court of March 13, 2001.

Gaygusuz v. Austria, European Court of Human Rights, September, 16, 1996.

Government of the Republic of South Africa and Others $v$ Grootboom and Others [2000] ZACC 19, 2001 (1) SA 46 (CC), 2000 (11) BCLR 1169 (CC).

Mayagna (Sumo) Community Awas Tingni v. Nicaragua, Inter-American Court of Human Rights, August 31, 2001.

Minister of Health and Others $v$ Treatment Action Campaign and Others (No 1) (CCT9/02) [2002] ZACC 16; 2002 (5) SA 703; 2002 (10) BCLR 1075 (5 July 2002).

Olga Tellis v. Bombay Municipal Corporation, 19853 SSC 545.

Pottinger v. City of Miami, 810 F. Supp.1551 (1992), 16th November 1992.

SERAC and CESR v. Nigeria, African Commission on Human and Peoples' Rights, Communication No 155/96, October 13-27, 2001.

\section{Website}

Antara News. "Warga NTB Berharap Menkeu Pahami Gugatan Divestasi". Available from http://mataram.antaranews.com/print/17622/warga-ntb-berharap-menkeu-pahamigugatan-divestasi [Accessed on 30 October 2014].

Hukumonline.com. "Lapindo dan Pemerintah Digugat Lagi". Available from http://www.hukumonline.com/detail.asp?id=16205Ecl=Berita [Accessed on 15 October 2014].

Hukumonline.com. "Pemerintah dan Lapindo Sudah Bertanggungjawab, Gugatan YLBHI Ditolak". Available from http://www.hukumonline.com/detail.asp?id= $\underline{18074 \mathcal{E} c l=\text { Berita }}$ [Accessed on 15 October 2014].

Hukumonline.com. "YLBHI Resmi Ajukan Banding". Available from http://www. hukumonline.com/detail.asp? id=18159Ecl=Berita [Accessed on 15 October 2014].

Human Rights Features. "A Fair Deal: Justiciability of ESC Rights". Available from http://www.hrdc.net/sahrdc/hrfchr58/Issue3.htm\#A\%20fair\%20deal 